Case Report

\title{
Acute Unilateral Renal Infarction in the Setting of an Inherited Thrombophilia and Atrial Septal Defect
}

\author{
Siavash Piran and Sam Schulman \\ Department of Medicine, Division of Hematology and Thromboembolism and Thrombosis and Atherosclerosis Research Institute, \\ McMaster University, Hamilton, ON, Canada \\ Correspondence should be addressed to Siavash Piran; siavash.piran@medportal.ca
}

Received 18 May 2017; Accepted 31 July 2017; Published 27 August 2017

Academic Editor: Kate Khair

Copyright (C) 2017 Siavash Piran and Sam Schulman. This is an open access article distributed under the Creative Commons Attribution License, which permits unrestricted use, distribution, and reproduction in any medium, provided the original work is properly cited.

\begin{abstract}
We present a case of renal infarction in a 43-year-old female with history of stroke at age 14 . She was found to be heterozygous for the prothrombin G20210A gene mutation. Loop monitoring revealed no atrial fibrillation. Transthoracic and transesophageal echocardiograms showed no thrombus. However, there was a small shunt due to an atrial septal defect (ASD). She was treated with warfarin and had device closure of her ASD. This was a suspected case of paradoxical embolism through an ASD leading to renal infarction.
\end{abstract}

\section{Introduction}

Paradoxical embolism is a rare but increasingly recognized cause of embolic events. An atrial septal abnormality such as a patent foramen ovale (PFO) or an atrial septal defect (ASD) serves as a pathway for a thrombus from the peripheral veins, bypassing the lungs, and entering the systemic circulation [1]. Cryptogenic stroke is the most commonly described presentation in patients with paradoxical embolism [2]. Renal infarction secondary to paradoxical embolism has rarely been described. Here, we report a case of a paradoxical embolism caused by ASD involving only one kidney in the setting of an inherited thrombophilia.

\section{Case Presentation}

A 43-year-old female was seen in consultation at our thrombosis clinic. She had a stroke at age 14 and had presented with collapse and left sided hemiparesis. Her thrombophilia workup was positive for a prothrombin G20210A gene mutation in heterozygous form. She had been on aspirin $81 \mathrm{mg}$ daily since age 14.

Prior to being diagnosed with a renal infarct at age 42 , the patient presented with nausea, vomiting, hematuria, and left flank pain and was initially diagnosed as renal colic. She subsequently had a computerized tomography scan of the abdomen and pelvis, which showed evidence of a wedge-shaped area in the lower pole of the left kidney consistent with a renal infarction. She was not on an oral contraceptive. We started treatment with intravenous heparin and transitioned to warfarin for 15 months without any further thromboembolic events.

Given that cardioembolic sources are well-documented causes of renal infarction [3], the patient had loop monitoring for two weeks and electrocardiograms, which did not detect atrial fibrillation. She also had two echocardiograms, none of which showed any evidence of cardiac thrombus. A transthoracic echocardiogram was performed with agitated saline at rest and after valsalva maneuver, which showed mild to moderate degree of shunting at rest that increased significantly with the release phase of a valsalva maneuver. This was suspicious for a PFO. A follow-up transesophageal echocardiogram showed a small left to right shunt due to a small ASD rather than a PFO. The patient had device closure of the ASD with no evidence of any remaining shunt on a transthoracic echocardiogram. It is likely that the patient's renal infarction was related to paradoxical embolism caused by small deep vein thrombosis migrating through the ASD shunt.

After 4 months of being off of anticoagulation, patient had a D-dimer test, which was positive at $591 \mu \mathrm{g} / \mathrm{L}$. There were no other reasons for the elevated D-dimer. Based on 
TABLE 1: Case reports of renal infarction associated with paradoxical embolism in the setting of a patent foramen ovale.

\begin{tabular}{|c|c|c|c|c|c|c|}
\hline Study & $\begin{array}{c}\text { Garachemani et } \\
\text { al. }\end{array}$ & Iwasaki et al. & Jeong et al. & Ekinci et al. & $\begin{array}{l}\text { Vilbert and } \\
\text { Franciosa }\end{array}$ & Khoma et al. \\
\hline $\begin{array}{l}\text { Year of publication } \\
\text { [Ref] }\end{array}$ & $2007[12]$ & $2011[13]$ & $2012[14]$ & 2014 [15] & $2016[16]$ & 2016 [17] \\
\hline $\begin{array}{l}\text { Renal (unilateral } \\
\text { versus bilateral, side) }\end{array}$ & $\begin{array}{l}\text { Unilateral, left } \\
\text { side }\end{array}$ & $\begin{array}{l}\text { Unilateral, right } \\
\text { side }\end{array}$ & $\begin{array}{l}\text { Unilateral, right } \\
\text { side }\end{array}$ & $\begin{array}{l}\text { Unilateral, left } \\
\text { side }\end{array}$ & $\begin{array}{l}\text { Unilateral, left } \\
\text { side }\end{array}$ & $\begin{array}{l}\text { Unilateral, left } \\
\text { side }\end{array}$ \\
\hline $\begin{array}{l}\text { Venous } \\
\text { thromboembolism } \\
\text { detected }\end{array}$ & $\begin{array}{c}\text { No } \\
\text { investigations } \\
\text { performed } \\
\end{array}$ & $\begin{array}{l}\text { No DVTs } \\
\text { detected }\end{array}$ & $\begin{array}{l}\text { No DVTs or PE } \\
\text { detected }\end{array}$ & $\begin{array}{c}\text { No } \\
\text { investigations } \\
\text { performed } \\
\end{array}$ & $\begin{array}{l}\text { No DVTs } \\
\text { detected }\end{array}$ & $\begin{array}{l}\text { No DVTs } \\
\text { detected }\end{array}$ \\
\hline Thrombophilia & $\begin{array}{c}\text { No } \\
\text { investigations } \\
\text { performed }\end{array}$ & Negative screen & Negative screen & Negative screen & $\begin{array}{c}\text { Prothrombin } \\
\text { G20210A } \\
\text { mutation }\end{array}$ & Negative screen \\
\hline $\begin{array}{l}\text { Other VTE risk } \\
\text { factors }\end{array}$ & None & None & None & None & $\mathrm{OCP}$ & $\begin{array}{c}\text { After bariatric } \\
\text { surgery }\end{array}$ \\
\hline $\begin{array}{l}\text { Other organ } \\
\text { involvement }\end{array}$ & $\begin{array}{c}\text { Myocardial } \\
\text { infarction }\end{array}$ & None & None & None & None & None \\
\hline Anticoagulation & $\begin{array}{c}\text { Oral } \\
\text { anticoagulation } \\
\text { type and } \\
\text { duration } \\
\text { unspecified } \\
\end{array}$ & $\begin{array}{c}\text { Secondary } \\
\text { prevention with } \\
\text { aspirin } 100 \mathrm{mg} \\
\text { daily }\end{array}$ & IV heparin & $\begin{array}{l}\text { Enoxaparin } \\
60 \mathrm{mg} \text { twice } \\
\text { daily }\end{array}$ & $\begin{array}{l}\text { IV heparin } \\
\text { transitioned to } \\
\text { warfarin, } \\
\text { 6-month } \\
\text { duration }\end{array}$ & $\begin{array}{l}\text { Warfarin, } \\
6 \text {-month } \\
\text { duration }\end{array}$ \\
\hline Device closure & Yes & Not specified & Planned & Not specified & Not planned & Planned \\
\hline
\end{tabular}

DVT: deep vein thrombosis; IV: intravenous; OCP: oral contraceptive pill; PE: pulmonary embolism.

an annual risk of recurrence of approximately ten percent in females with a first unprovoked venous thromboembolism (VTE) event and a positive D-dimer, the patient was restarted back of warfarin [4].

\section{Discussion}

Prothrombin gene mutation is the second most common inherited thrombophilia with a prevalence of approximately $2 \%$ [5]. The risk of VTE in individuals who are heterozygous for the prothrombin G20210A mutation is approximately 34 -fold compared with a control group $[6,7]$. It is unclear if the prothrombin gene mutation increases the risk of VTE recurrence, with some studies suggesting an increased risk [8] while others not $[9,10]$. It is generally known that the prothrombin gene mutation is not associated with an increased risk of arterial thrombosis. However, a 2017 metaanalysis reported a slightly increased risk of stroke in children and young adults with the prothrombin gene mutation [11].

There are several case reports of paradoxical embolism causing renal infarction through a $\mathrm{PFO}$ in presence or absence of a thrombophilia (Table 1) [12-17]. However, to our knowledge, this is the first report of a renal infarction due to paradoxical embolism in the setting of an ASD and thrombophilia. Paradoxical embolism is a rare cause of renal infarction; however the role of an atrial septal abnormality as a source of embolic events in various organs is increasingly recognized.

\section{Conclusions}

Our case report identifies paradoxical embolism causing renal infarction through an ASD and highlights the need for immediate identification of a paradoxical embolism so that anticoagulation can be started and device closure can be considered to prevent further embolic events in other organs.

\section{Consent}

Informed consent was obtained from the patient to publish the case report.

\section{Conflicts of Interest}

Siavash Piran has nothing to disclose; Sam Schulman reports receiving consulting fees from Boehringer Ingelheim, BristolMyer-Squibb, Bayer, and Daichii and grant support from Boehringer Ingelheim, Baxter, and Octapharma.

\section{References}

[1] C. N. Dao and J. M. Tobis, "PFO and paradoxical embolism producing events other than stroke," Catheterization and Cardiovascular Interventions, vol. 77, no. 6, pp. 903-909, 2011.

[2] C. Lamy, C. Giannesini, M. Zuber et al., "Clinical and imaging findings in cryptogenic stroke patients with and without patent foramen ovale: the PFO-ASA study," Stroke, vol. 33, no. 3, pp. 706-711, 2002.

[3] Y. K. Oh, C. W. Yang, Y. Kim et al., "Clinical Characteristics and Outcomes of Renal Infarction," American Journal of Kidney Diseases, vol. 7, no. 2, pp. 243-250, 2016.

[4] J. Douketis, A. Tosetto, M. Marcucci et al., "Patient-level metaanalysis: Effect of measurement timing, threshold, and patient age on ability of D-dimer testing to assess recurrence risk after unprovoked venous thromboembolism," Annals of Internal Medicine, vol. 153, no. 8, pp. 523-531, 2010. 
[5] F. R. Rosendaal, C. J. Doggen, A. Zivelin et al., "Geographic distribution of the $20210 \mathrm{G}$ to A prothrombin variant," Thromb Haemost, vol. 79, no. 4, p. 706, 1998.

[6] C. Leroyer, B. Mercier, E. Oger et al., "Prevalence of 20210 A allele of the prothrombin gene in venous thromboembolism patients," Thrombosis and Haemostasis, vol. 80, no. 1, pp. 49-51, 1998.

[7] M. Margaglione, V. Brancaccio, N. Giuliani et al., "Increased risk for venous thrombosis in carriers of the prothrombin G> A20210 gene variant," Annals of Internal Medicine, vol. 129, no. 2, pp. 89-93, 1998.

[8] P. Simioni, P. Prandoni, and A. W. Lensing, "Risk for subsequent venous thromboembolic complications in carriers of the prothrombin or the factor $\mathrm{V}$ gene mutation with a first episode of deep-vein thrombosis," Blood, vol. 96, no. 10, p. 3329, 2000.

[9] S. Eichinger, E. Minar, M. Hirschl et al., "The risk of early recurrent venous thromboembolism after oral anticoagulant therapy in patients with the G20210A transition in the prothrombin gene," Thrombosis and Haemostasis, vol. 81, no. 1, pp. 14-17, 1999.

[10] V. De Stefano, I. Martinelli, P. M. Mannucci et al., "The risk of recurrent venous thromboembolism among heterozygous carriers of the G20210a prothrombin gene mutation," British Journal of Haematology, vol. 113, no. 3, pp. 630-635, 2001.

[11] B. Sarecka-Hujar, I. Kopyta, M. Skrzypek, and J. Sordyl, "Association Between the 20210G>A Prothrombin Gene Polymorphism and Arterial Ischemic Stroke in Children and Young Adults-Two Meta-analyses of 3586 Cases and 6440 Control Subjects in Total," Pediatric Neurology, vol. 69, p. 93, 2017.

[12] A. Garachemani, P. Eshtehardi, and B. Meier, "Paradoxical emboli through the patent foramen ovale as the suspected cause of myocardial and renal infarction in a 48-year-old woman," Catheterization and Cardiovascular Interventions, vol. 70, no. 7, pp. 1010-1012, 2007.

[13] M. Iwasaki, N. Joki, Y. Tanaka, H. Hara, M. Suzuki, and H. Hase, "A suspected case of paradoxical renal embolism through the patent foramen ovale," Clinical and Experimental Nephrology, vol. 15, no. 1, pp. 147-150, 2011.

[14] H. Jeong, H. Woo Lee, J. Young Joung et al., "Renal infarction caused by paradoxical embolism through a patent foramen ovale," Kidney Research and Clinical Practice, vol. 31, no. 3, pp. 196-199, 2012.

[15] I. Ekinci, S. A. Dae, E. Asoğlu et al., "A rare cause of renal infarct: Paradoxical embolism through the patent foramen ovale," Int $J$ Urol Nephrol, vol. 2, no. 3, pp. 55-58, 2014.

[16] E. M. Vilbert and S. V. Franciosa, "Acute Renal Infarction With Heritable Coagulopathy and Patent Foramen Ovale," Radiology Case Reports, vol. 4, no. 2, p. 260, 2016.

[17] O. Khoma, A. Suppiah, and D. Martin, "Case report: Renal infarction by paradoxical embolism through the patent foramen ovale as an unusual cause of post-operative abdominal pain after sleeve gastrectomy," International Journal of Surgery Case Reports, vol. 26, pp. 47-49, 2016. 


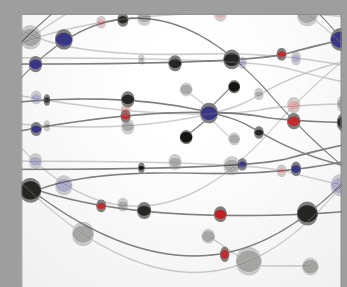

The Scientific World Journal
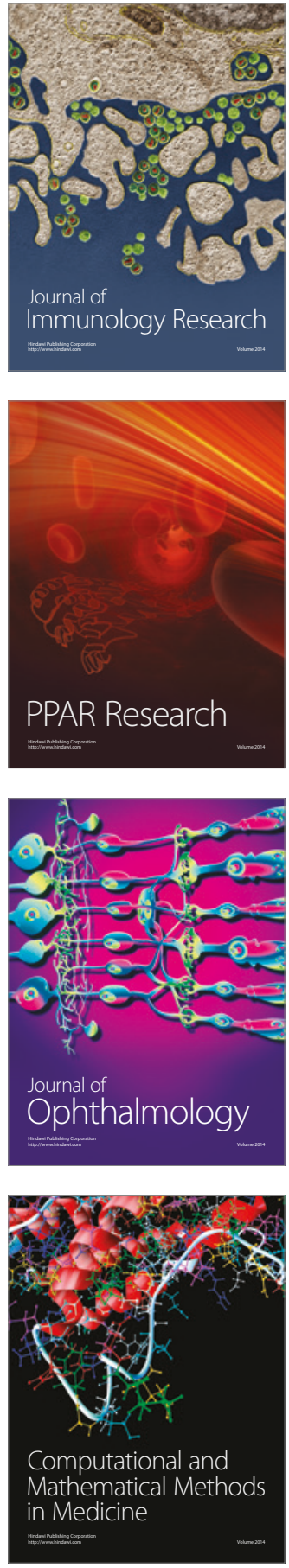

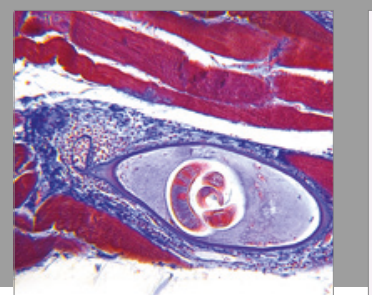

Gastroenterology Research and Practice
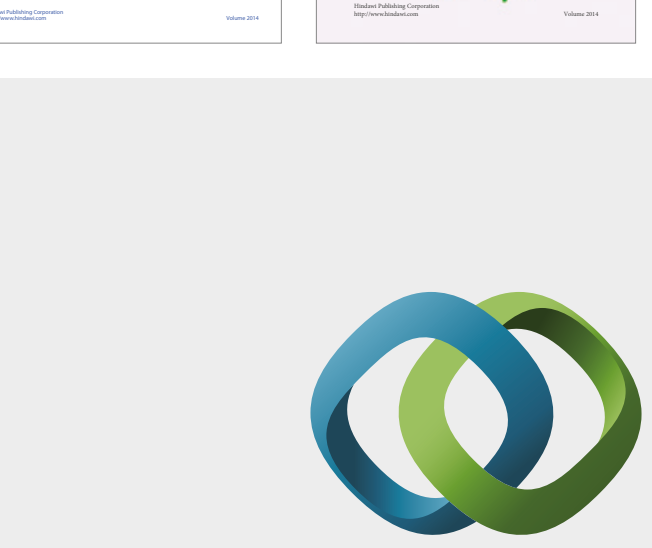

\section{Hindawi}

Submit your manuscripts at

https://www.hindawi.com
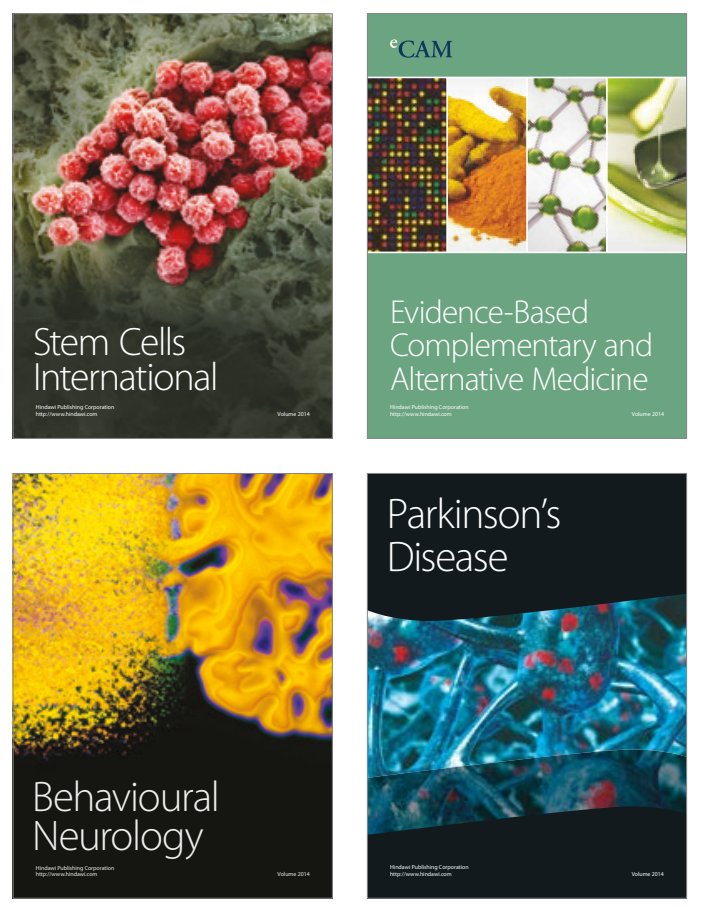
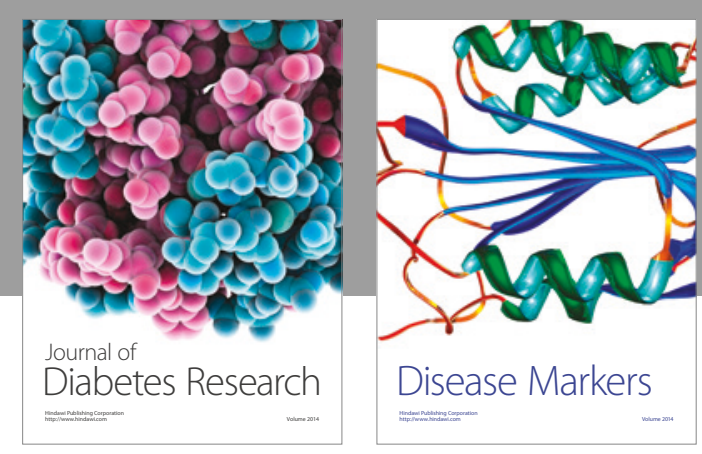

Disease Markers
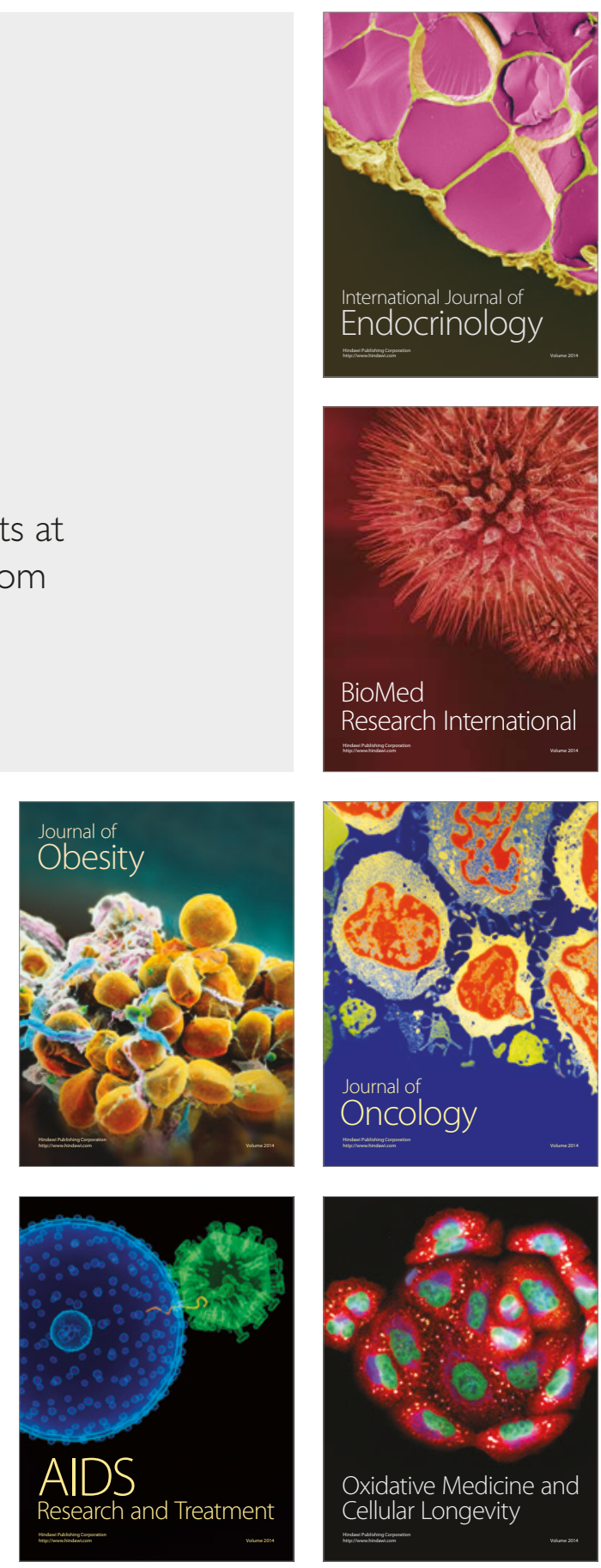